\title{
Effects of Biochemical Alteration in Animal Model after Short-Term Exposure of Jatropha curcas (Linn) Leaf Extract
}

\author{
Osamuyimen O. Igbinosa, ${ }^{1}$ Efosa F. Oviasogie, ${ }^{2}$ Etinosa O. Igbinosa, ${ }^{2,3}$ \\ Otibhor Igene, ${ }^{4}$ Isoken H. Igbinosa, ${ }^{3}$ and Omoruyi G. Idemudia ${ }^{5}$ \\ ${ }^{1}$ Department of Medicine, Saint Peter's University Hospital, New Brunswick, NJ, USA \\ ${ }^{2}$ Department of Microbiology, Faculty of Life Sciences, University of Benin, Benin City, Nigeria \\ ${ }^{3}$ Department of Biochemistry and Microbiology, University of Fort Hare, Private Bag X1314, Alice 5700, South Africa \\ ${ }^{4}$ College of Medicine, America University of Antigua, Antigua And Barbuda \\ ${ }^{5}$ Department of Chemistry, University of Fort Hare, Private Bag X1314, Alice 5700, South Africa
}

Correspondence should be addressed to Etinosa O. Igbinosa; eigbinosa@gmail.com

Received 25 March 2013; Accepted 5 May 2013

Academic Editors: H.-W. Chang, S. Guleria, and S. Yasmin

Copyright (c) 2013 Osamuyimen O. Igbinosa et al. This is an open access article distributed under the Creative Commons Attribution License, which permits unrestricted use, distribution, and reproduction in any medium, provided the original work is properly cited.

This study aims to evaluate potential toxic effect of Jatropha curcas leaves methanol extract on laboratory rats as well as determine its $\mathrm{LD}_{50}$. A total of 80 male Wistar rats were used as the experimental animals, 40 for $\mathrm{LD}_{50}$ determination and the other 40 for toxicity study. Based on the pretest that was done in order to establish a range of toxicity, 4 dosages $(86.00,58.00,46.00$, and $34.0 \mathrm{~kg} / \mathrm{body}$ weight) were chosen. The rats were randomly assigned into four groups with 10 rats in each group. Rats in groups 1, 2, 3, and 4 were given $0 \mathrm{mg} / \mathrm{kg}, 500 \mathrm{mg} / \mathrm{kg}, 1000 \mathrm{mg} / \mathrm{kg}$, and $2000 \mathrm{mg} / \mathrm{kg}$ body weight of Jatropha curcas extract, respectively, by oral intubation for 21 days. Thereafter, clinical signs, change in body weight, toxicity symptoms, and biochemical parameters were obtained. The $\mathrm{LD}_{50}$ at $95 \%$ confidence limits for rats was $46.0 \mathrm{mg} / \mathrm{kg}$ body weight $(44.95-52.69 \mathrm{mg} / \mathrm{kg}$ body mass). There was no clinical and biochemical signs of toxicity when the extract was administered at 500, 1000, and $2000 \mathrm{mg} / \mathrm{kg}$ body weight, respectively $(P>0.05)$. Results obtained from this study suggest that liver, kidney, and haematological system of rats tolerated methanolic leave extract of Jatropha curcas at a certain concentration.

\section{Introduction}

The continued interest in the evaluation of natural products as potential chemotherapeutic agents is encouraged by the isolation of phytochemicals in the plants, which could become important drugs in modern medicine. Plants produce bioactive compounds or molecules that act as defence mechanisms against predators and at the same time may be toxic in nature $[1,2]$. With the increased interest in medicinal plants, there is a need for thorough scientific investigations of these plants for efficacy and potential toxicity.

Jatropha curcas (Linn) belonging to the family Euphorbiaceae is a shrub that grows 4.5 to 8 meters high. The roots, leaves, and seeds of the plant have been widely used in traditional folk medicine in many parts of West Africa, Central and South America. Previous studies have shown that the plant exhibits bioactive activities for fever, mouth infections, jaundice, and guinea worm sores [3]. FagbenroBeyioku et al. [4] reported antiparasitic activity of the sap and crushed leaves of $J$. curcas. The water extract of the branches also strongly inhibited HIV-induced cytopathic effects with low cytotoxicity [5]. Mujumdar et al. [6] also reported that the crude methanol extract from the root of $J$. curcas exhibited antidiarrheal activity in mice through inhibition of prostaglandin biosynthesis and reduction of osmotic pressure. Our biological study on J. curcas reported relevant antimicrobial efficacy and antioxidant activities [7, 8]. Balaji et al. [9] reported that methanol extract of J. curcas could protect liver against the aflatoxin B1-induced oxidative damage in rats. Despite all beneficial effects of J. curcas, some studies have also demonstrated that J. curcas exhibited toxicity especially in higher animals. For example, methanol, petroleum 
ether, and dichloromethane extracts of J. curcas fruit caused fetal resorption indicating pregnancy terminating effect in rats [10]. Methanol fraction from J. curcas oil induced tumor promotion upon topical initiation by Makkar et al. [11], dimethylbenz(a)anthracene (DMBA) in mice, with $36 \%$ of the animals having skin tumors in 30 weeks [12]. Raw or defatted seeds when administered to fish, chicks, pigs, goats, mice, and rats were associated with toxic symptoms before death $[13,14]$. Different aqueous extracts also exhibited different toxic symptoms depending on dose, mode of administration, and sensitivity of the animals that were tested $[15,16]$.

In recent times, concerns have been raised over the lack of quality control and scientific facts for the efficacy and safety of medical plants $[17,18]$. Cautions have been raised regarding the potential adverse effects of herbal remedies including hepatotoxicity and nephrotoxicity $[19,20]$, even as it is known that medicinal plants typically contain several different pharmacologically active compounds that may act individually, additively, or in synergy to improve health $[8$, $21,22]$. It has been reported that $80 \%$ of the population in the developing world still rely on traditional medicine for primary health care needs. In spite of the diverse uses of plants in folk medicine, there seems to be dearth of information on the possible toxicity of this plant. Therefore, this study evaluates the toxicity risk of the methanol extract of the plant leaves of J. curcas using animal model.

\section{Results and Discussion}

2.1. Clinical Signs and Mortality. Death of rats administered with J. curcas extract occurred at a dose-dependent manner with starting dose of $34 \mathrm{mg} / \mathrm{kg}$ (Table 1). At the highest dose of $86.0 \mathrm{mg} / \mathrm{kg}$, majority of rats were easily affrighted and stayed crouched together and tend not to eat much. Before rats died, they exhibited signs of depression, closing of eyes, languishment, loss of body mass, and black excreta. Rats began to die on day 2 after administering J. curcas extract, continued with a majority of deaths occurring within 7 days. There was no death recorded between observation days, 12 and 21 days.

Table 2 shows the effect of $J$. curcas extract on weight gain, food intake, and fecal output. The result obtained indicates that weight gain, food intake, and fecal output of rat treated with 500,1000 , and $2000 \mathrm{mg} / \mathrm{kg}$ body weight of extract were not significantly different $(P>0.05)$. The effects of oral administration of the leaf extract of $J$. curcas at the doses investigated on RBCs and its functional indices in laboratory rats (Wistar) for 21 days are shown in Table 3. The extract did not significantly alter the level of $\mathrm{Hg}, \mathrm{RBC}, \mathrm{PCV}, \mathrm{MCHC}$, and LUC. The administration of the extract effectively reduced the level of WBC and the differentials including basophils, monocytes and platelets throughout the study period (Table 3).

The plant extract showed varied effects on the kidney and its functional indices (Table 3). The levels of sodium, potassium, calcium, urea, and creatinine were not significantly affected when compared with the control animal model. In contrast, however, the level of chlorine ion was decreased as doses dependent factor. The extract did not significantly alter the level of albumin and total bilirubin which is the vital assay
TABLE 1: Determination of the $\mathrm{LD}_{50}$ value.

\begin{tabular}{lcccccccccccccc}
\hline \multirow{2}{*}{ Dose $(\mathrm{mg} / \mathrm{kg})$} & Total dead & \multicolumn{1}{c}{ Days after administration } & \\
& & 0 & 1 & 2 & 3 & 4 & 5 & 6 & 7 & 8 & 9 & 10 & 11 & $12-21$ \\
\hline 86.0 & 9 & 0 & 0 & 2 & 0 & 1 & 1 & 1 & 2 & 1 & 0 & 0 & 1 & 0 \\
58.0 & 7 & 0 & 0 & 0 & 1 & 1 & 2 & 2 & 0 & 0 & 1 & 0 & 0 & 0 \\
46.0 & 4 & 0 & 0 & 1 & 0 & 1 & 0 & 0 & 1 & 0 & 0 & 0 & 1 & 0 \\
34.0 & 2 & 0 & 0 & 0 & 0 & 0 & 1 & 0 & 0 & 0 & 0 & 1 & 0 & 0 \\
Control & 0 & 0 & 0 & 0 & 0 & 0 & 0 & 0 & 0 & 0 & 0 & 0 & 0 & 0 \\
\hline
\end{tabular}

in assessing liver damage (Table 3). There was no significant difference in the parameters measured in rats administered with 500,1000, and $2000 \mathrm{mg} / \mathrm{kg}$ body weight of J. curcas extract. These parameters include alanine aminotransferases (ALT), aspartate aminotransferases (AST), alkaline phosphatase (ALP), gamma glutamyl transferase (GGT), and blood urea nitrogen (BUN) (Table 3).

2.2. Discussion. J. curcas has been a multipurpose perennial plant which has lots of industrial and a long history of various medicinal applications. Antimicrobial and antioxidant activities of $J$. curcas were scientifically established $[7,8]$. Since several reports have highlighted toxicity of this plant, this study ascertains safe dose of methanolic leave extract of $J$. curcas using animal model.

There are many methods used in calculating $\mathrm{LD}_{50}$ such as the graphical method of Miller and Tainter, arithmetical method of Karber, and statistical approach which include upand-down procedure, fixed dose procedure, acute toxic class method, Bliss method, and sequential grouping method. Bliss [23] developed the idea of transforming the sigmoid doseresponse curve to a straight line. In 1952, Finney popularized Bliss' idea in a book called Probit Analysis [24]. Bliss method being classical is still the preferred statistical method. Li et al. [25] in understanding dose-response relationship the procedure was used in our study.

$\mathrm{LD}_{50}$ study indicated that J. curcas leave extract is toxic to rats at a high dose, and rats develop severe pathological symptoms. The obtained lethal dose as shown in this study may not predict the human lethal dose of a drug or acute poisoning overdose. However, it was used to provide a guideline for selecting doses for subacute dosage of more clinical relevance. Feeding studies on J. curcas showed severe clinical and pathological symptoms in a dose-dependent manner [26, 27]; symptoms observed include transient loss of body mass and mild to severe macroscopic and microscopic changes in the kidney, lungs, heart, liver, and spleen. In the present study, the observed dark excreta may be suggestive of gastrointestinal hemorrhage.

The treatment of animals at doses 500, 1000, and $2000 \mathrm{mg} / \mathrm{kg}$ for 21 days show selective toxic effect on some biochemical and hematological parameters. These parameters are used to determine the possible alterations in the level of biomolecules such as enzymes, metabolic product, normal functioning and histomorphology of the organs. There were no noticeable hemolytic changes in the plasma of the extract treated rats on $\mathrm{RBC}, \mathrm{Hg}, \mathrm{PCV}, \mathrm{MCHC}$, and LUC. These 
TABLE 2: Weight gain, food consumption, and fecal output of rats administered $J$. curcas extract $(n=6$, mean \pm SD).

\begin{tabular}{lcccc}
\hline \multirow{2}{*}{ Parameter } & & \multicolumn{2}{c}{ Dose of extract (mg/kg body weight) } & \\
& Control & 500 & 1000 & 2000 \\
\hline Weight gain (g/day/rat) & $1.52 \pm 0.23^{\mathrm{a}}$ & $1.64 \pm 0.45^{\mathrm{b}}$ & $1.57 \pm 0.65^{\mathrm{b}}$ & $1.2 \pm 0.59^{\mathrm{d}}$ \\
Food intake (g/day/rat) & $21.34 \pm 1.32^{\mathrm{a}}$ & $24.93 \pm 0.32^{\mathrm{b}}$ & $25.01 \pm 1.24^{\mathrm{d}}$ & $23.82 \pm 1.51^{\mathrm{e}}$ \\
Dry fecal output (g/day/rat) & $1.34 \pm 0.09^{\mathrm{a}}$ & $1.29 \pm 0.05^{\mathrm{c}}$ & $1.41 \pm 0.06^{\mathrm{c}}$ & $2.01 \pm 0.03^{\mathrm{e}}$ \\
\hline
\end{tabular}

Means with the same letter are not significantly different $(P<0.05)$.

TABLE 3: Effects of methanolic leaf extract of $J$. curcas on plasma biochemical parameters of laboratory rats $(n=6$, mean \pm SD).

\begin{tabular}{|c|c|c|c|c|}
\hline \multirow{2}{*}{ Parameter } & \multicolumn{4}{|c|}{ Doses of extract (mg/kg body weight) } \\
\hline & Control & 500 & 1000 & 2000 \\
\hline $\operatorname{ALT}(\mathrm{U} / \mathrm{L})$ & $21.03 \pm 0.47^{\mathrm{a}}$ & $19.93 \pm 0.83^{\mathrm{ab}}$ & $22.03 \pm 0.93^{\mathrm{ab}}$ & $25.07 \pm 1.85^{\mathrm{a}}$ \\
\hline AST (U/L) & $19.05 \pm 1.03^{\mathrm{a}}$ & $24.05 \pm 0.93^{\mathrm{a}}$ & $25.47 \pm 0.46^{\mathrm{ab}}$ & $24.93 \pm 1.09^{\mathrm{a}}$ \\
\hline $\operatorname{ALP}(\mathrm{U} / \mathrm{L})$ & $43.03 \pm 0.84^{\mathrm{a}}$ & $48.03 \pm 1.03^{\mathrm{a}}$ & $45.04 \pm 1.39^{\mathrm{a}}$ & $51.09 \pm 3.04^{\mathrm{a}}$ \\
\hline GGT (U/L) & $28.72 \pm 3.29^{\mathrm{a}}$ & $29.54 \pm 4.12^{\mathrm{ab}}$ & $30.60 \pm 2.46^{\mathrm{a}}$ & $33.62 \pm 3.01^{\mathrm{ab}}$ \\
\hline Albumin $(\mathrm{mmol} / \mathrm{L})$ & $19.50 \pm 0.85^{\mathrm{a}}$ & $19.12 \pm 0.15^{\mathrm{a}}$ & $18.56 \pm 1.74^{\mathrm{a}}$ & $17.31 \pm 2.10^{\mathrm{a}}$ \\
\hline Total bilirubin $(\mu \mathrm{mol} / \mathrm{L})$ & $12.53 \pm 0.71^{\mathrm{a}}$ & $11.38 \pm 0.21^{\mathrm{a}}$ & $11.01 \pm 2.08^{\mathrm{a}}$ & $9.50 \pm 0.53^{\mathrm{a}}$ \\
\hline Total protein $(\mathrm{g} / \mathrm{L})$ & $6.07 \pm 0.52^{\mathrm{a}}$ & $7.99 \pm 0.62^{b}$ & $5.80 \pm 0.32^{b}$ & $5.94 \pm 0.46^{\mathrm{a}}$ \\
\hline BUN (mg/dL) & $8.03 \pm 2.01^{\mathrm{a}}$ & $10.90 \pm 1.84^{\mathrm{ab}}$ & $9.91 \pm 0.73^{\mathrm{a}}$ & $11.05 \pm 1.89^{\mathrm{b}}$ \\
\hline Glucose (mmol/L) & $5.59 \pm 0.01^{\mathrm{a}}$ & $5.78 \pm 0.01^{\mathrm{a}}$ & $5.71 \pm 0.02^{\mathrm{a}}$ & $5.40 \pm 0.20^{\mathrm{a}}$ \\
\hline Potassium (mmol/L) & $6.95 \pm 1.13^{\mathrm{a}}$ & $5.52 \pm 0.18^{\mathrm{a}}$ & $5.94 \pm 0.15^{\mathrm{a}}$ & $5.96 \pm 0.25^{\mathrm{a}}$ \\
\hline Sodium (mmol/L) & $145.33 \pm 2.51^{\mathrm{a}}$ & $146.52 \pm 3.17^{\mathrm{a}}$ & $143.76 \pm 0.68^{\mathrm{a}}$ & $141.98 \pm 0.82^{\mathrm{a}}$ \\
\hline Chloride (mmol/L) & $125.5 \pm 3.52^{\mathrm{a}}$ & $110.45 \pm 2.53^{\mathrm{ab}}$ & $98.51 \pm 1.15^{\mathrm{a}}$ & $95.78 \pm 1.58^{\mathrm{a}}$ \\
\hline Calcium (mmol/L) & $5.54 \pm 0.12^{\mathrm{a}}$ & $4.85 \pm 0.01^{\mathrm{a}}$ & $5.01 \pm 0.05^{\mathrm{b}}$ & $5.15 \pm 0.04^{\mathrm{a}}$ \\
\hline Urea $(\mathrm{mmol} / \mathrm{L})$ & $6.08 \pm 0.21^{\mathrm{a}}$ & $7.89 \pm 1.50^{\mathrm{a}}$ & $7.45 \pm 0.58^{\mathrm{a}}$ & $6.50 \pm 0.15^{\mathrm{a}}$ \\
\hline Creatinine $(\mathrm{mmol} / \mathrm{L})$ & $0.56 \pm 0.23^{\mathrm{ab}}$ & $0.73 \pm 0.23^{\mathrm{b}}$ & $0.48 \pm 0.35^{\mathrm{a}}$ & $0.66 \pm 0.34^{\mathrm{b}}$ \\
\hline WBC count $\left(\times 10^{9} / \mathrm{L}\right)$ & $16.20 \pm 2.5^{\mathrm{a}}$ & $7.53 \pm 1.60^{\mathrm{b}}$ & $9.02 \pm 1.5^{\mathrm{b}}$ & $8.9 \pm 2.4^{\mathrm{b}}$ \\
\hline Platelets $\left(\times 10^{9} / \mathrm{L}\right)$ & $789.45 \pm 5.84^{\mathrm{a}}$ & $734.01 \pm 2.52^{c}$ & $650.53 \pm 7.89^{c}$ & $645.32 \pm 3.50^{\mathrm{b}}$ \\
\hline Basophils (\%) & $0.85 \pm 0.51^{\mathrm{a}}$ & $0.55 \pm 0.01^{\mathrm{a}}$ & $0.53 \pm 0.21^{\mathrm{a}}$ & $0.50 \pm 0.35^{\mathrm{a}}$ \\
\hline Monocytes (\%) & $27.56 \pm 3.21^{\mathrm{a}}$ & $15.65 \pm 4.50^{c}$ & $12.89 \pm 5.01^{\mathfrak{c}}$ & $18.98 \pm 2.51^{\mathrm{b}}$ \\
\hline $\mathrm{Hg}(\mathrm{g} / \mathrm{L})$ & $12.80 \pm 1.6^{\mathrm{ab}}$ & $10.04 \pm 2.04^{\mathrm{a}}$ & $9.03 \pm 2.09^{\mathrm{ac}}$ & $8.9 \pm 1.76^{\mathrm{ab}}$ \\
\hline $\operatorname{RBC}\left(\times 10^{9} / \mathrm{L}\right)$ & $8.75 \pm 0.05^{\mathrm{a}}$ & $9.84 \pm 0.51^{\mathrm{a}}$ & $8.70 \pm 0.53^{\mathrm{a}}$ & $8.45 \pm 0.15^{\mathrm{a}}$ \\
\hline $\mathrm{PCV}(\mathrm{L} / \mathrm{L})$ & $0.50 \pm 0.03^{\mathrm{a}}$ & $0.52 \pm 0.2^{\mathrm{bc}}$ & $0.48 \pm 0.02^{\mathrm{ab}}$ & $0.47 \pm 0.04^{\mathrm{ac}}$ \\
\hline $\mathrm{MCHC}(\mathrm{g} / \mathrm{dL})$ & $29.50 \pm 1.52^{\mathrm{a}}$ & $32.55 \pm 0.52^{\mathrm{a}}$ & $31.81 \pm 1.20^{\mathrm{a}}$ & $31.50 \pm 0.51^{\mathrm{a}}$ \\
\hline LUC (\%) & $8.95 \pm 1.05^{\mathrm{a}}$ & $10.25 \pm 0.78^{\mathrm{a}}$ & $9.85 \pm 1.07^{\mathrm{a}}$ & $8.45 \pm 0.36^{\mathrm{a}}$ \\
\hline
\end{tabular}

Means with the same letter are not significantly different $(P<0.05)$.

Legend: alanine transaminase (ALT); aspartate transaminase (AST); alkaline phosphatase (ALP); gamma glutamyl transferase (GGT); blood urea nitrogen (BUN); haemoglobin (Hg); pack cell volume (PCV); white blood cell (WBC); red blood cell (RBC); mean corpuscular haemoglobin concentration (MCHC); large unstained cell (LUC).

indices are well known to determine the hemolytic damage on RBCs. The absence of changes on these functional properties suggests that the extract does not possess toxic substances that can cause anemic condition in rats. A decreased hemoglobin and hematocrit levels, indicative of anemia, is associated with hemolysis from antigen-antibody response. Rise in white blood cell (WBC) is generally considered to be a marker of stress and a defence mechanism triggered by immune system.

In this study, there was no significant difference in WBC and hemoglobin in all observed groups. The blood creatinine or urea nitrogen levels are indicative of renal function [28]. Awasthy et al. [29] reported significant increase in creatinine of rats when basal feed was supplemented with $25 \%$ and $50 \%$
Jatropha seed protein. However, administering J. curcas at doses far below $\mathrm{lD}_{50}(500,1000$, and $2000 \mathrm{mg} / \mathrm{kg}$ body $)$ in this study was not associated with significant change in weight, liver chemistry, and hematologic profile when compared with control.

Elevated serum transaminase activity is highly suggestive of hepatic impairment in animals [30]. Serum transaminases was reported to be significantly elevated in goats fed with $J$. curcas seeds at 0.25 to $10 \mathrm{~g} / \mathrm{kg} /$ day up to 21 days; 23 in calves orally administered J. curcas seeds in suspension at $0.25,1.0$, and $2.5 \mathrm{~g} / \mathrm{kg}$ within 14 days [31]. Also desert sheeps were fed with the seeds at 0.5 and $1.0 \mathrm{~g} / \mathrm{kg} /$ day [32]. The common denominator in the above toxicity studies is that they were all administered seeds. Our current study on J. curcas leaves 
did not show any significant increase in serum transaminase. This observation may be due to lower concentration phorbol esters in J. curcas leaves, exposure time, dose, and extraction type (methanolic extracts). Several compounds have been isolated from J. curcas seeds, it is reasonable to extrapolate that these compounds are present at lower concentration in the leaves as well. The compounds include saponins, lectins (curcin), phytates, protease inhibitors, curcalonic acid, and phorbol esters, but studies that isolate phorbol esters in toxic and non toxic strains have determined that phorbol esters as compounds of concern [28]. Phorbol esters are present in leaves, stems, flowers, and roots of J. curcas [11].

\section{Experimental Section}

3.1. Collection and Identification of Plant Materials. Fresh leaves of $J$. curcas were collected from a local farm in Benin City, Edo State, Nigeria, in the month of June 2010 and were identified by the Botany Department of Ambrose Alli University, Ekpoma, Nigeria.

3.2. Extraction of Plant Materials. Powdered plant materials $(100 \mathrm{~g}$ of each) were extracted with $1000 \mathrm{~mL}$ methanol in a Soxhlet apparatus for 8 hours. The obtained methanolic extracts were filtered and evaporated by using a rotary evaporator and freeze dryer to give the crude dried extract.

3.3. Experimental Animals. Total of 80 male Wistar ( 8 weeks old) rats were used as the experimental animals; 40 for $\mathrm{LD}_{50}$ determination and the other 40 for toxicity study. The animals were maintained in a room with controlled temperature $(35 \pm$ $2^{\circ} \mathrm{C}$ ) for $12 \mathrm{~h}$ light $/ 12 \mathrm{~h}$ dark cycle with food (standard pellet diet) and sterile water provided ad librium. The animals were habituated to the experimental room for at least $24 \mathrm{~h}$ before the experiments. After acclimatization, the mice were weighed and numbered. The experiment was conducted in a barrier system with an experimental facility. Animal studies were in compliance to the ethical procedure for the care and use of laboratory animals that corresponds with $\mathrm{NIH}$ guidelines.

3.4. Assay Kits. The assay kits for total protein, creatinine, urea, calcium, sodium, potassium, chloride, albumin, bilirubin, alkaline phosphatase (ALP), gamma glutamyltransferase (GGT), alanine aminotransferases (ALT), and aspartate aminotransferases (AST) were obtained from Bayer's Diagnostics, Baroda, India.

3.5. Determination of $L D_{50}$ of the Extract. Rats weighing $102 \pm 4.8 \mathrm{~g}$ were used for the determination of $\mathrm{LD}_{50}$ of the extract. Based on dose levels that decrease in geometrical progression, the regression equation between the probits of mortalities $(Y)$ and the log of doses $(D)$ was also derived: $Y$ (probit) $=-9.67+10.21 \log (D)$. Four $(4)$ doses $(86.00,58.00$, 46.00 , and $34.0 \mathrm{~kg} /$ body mass) were ultimately required for establishing the $\mathrm{LD}_{50}$. Calculation of $\mathrm{LD}_{50}$, was based on $95 \%$ confidence limits [33]. The Bliss was calculated by using the NDST Software Version 8.0 [34].
3.6. Toxicity Study Design. A pretest was conducted to observe the range of toxicity in others to establish dose range for $\mathrm{LD}_{50}$ determination. Three dose levels $(6,12$, and $18 \mathrm{mg} / \mathrm{kg}$ body mass) of methanoic leave extract of $J$. curcas were used for the pretesting. Based on the pretest results, 4 dosages (86.00, 58.00, 46.00, and $34.0 \mathrm{~kg} /$ body mass) were established with each group comprised of 10 rats using random block design.

The rats were randomly assigned into four groups with 10 rats in each group. Rats in groups 2, 3, and 4 were given 500,1000 , and $2000 \mathrm{mg} / \mathrm{kg}$ body weight, respectively, orally by intubation. Control rats (group 1) were administered the same volume of deionized water. The doses administered were below the $\mathrm{LD}_{50}$ of the extract which was found to be $46.0 \mathrm{~g} / \mathrm{kg}$ body weight of rat.

The rats were fed daily for two weeks. At the end of study period after fasting for 3 hours, each rat was anaesthetized in chloroform-saturated chamber. Under anesthesia, the abdominal and thoracic region of each rat was opened to assess the heart. The blood samples were collected through cardiac puncture in properly heparinized vials. The tube was swirled and placed on ice. Plasma was obtained from blood by centrifugation at $3000 \mathrm{rpm}$ for $5 \mathrm{~min}$. The different biochemical parameters were analyzed from blood plasma by using the diagnostic kits (Bayer's Diagnostics, Baroda, India) with the help of a semiautomated analyzer (RA-50 chemistry). Clinical signs, change in body mass, and toxicity symptoms were observed daily for 21 days.

3.7. Statistical Analysis. Experimental data were expressed as mean of six replicates and subjected to one way analysis of variance (ANOVA). Means were separated by Duncan multiple range test using the Statistical Analysis System (SAS version 8, SAS Institute, Cary, NC, USA). Values were considered statistically significant level at $P<0.05$.

\section{Conclusions}

In conclusion, although direct extrapolation of results from animal models cannot be applied to humans, results obtained from this study suggest that the liver, kidney, and hematological system of rats tolerated leave extract of J. curcas at a certain concentration. However, histopathology study is desirable to confirm these findings. One issue that remains unsolved is the efficacy of this plant under investigation at nontoxic doses.

\section{Acknowledgment}

The authors thank the Govan Mbeki Research and Development Centre (GMRDC) of the University of Fort Hare, Alice South Africa, for the facilities provided in the course of preparing this paper.

\section{References}

[1] A. B. Da Rocha, R. M. Lopes, and G. Schwartsmann, "Natural products in anticancer therapy," Current Opinion in Pharmacology, vol. 1, no. 4, pp. 364-369, 2001. 
[2] S. Bent and R. Ko, "Commonly used herbal medicines in the United States: a review," The American Journal of Medicine, vol. 116, no. 7, pp. 478-485, 2004.

[3] B. Oliver-Bever, Medicinal Plants in Tropical West Africa, Cambridge University Press, London, UK, 1986.

[4] A. F. Fagbenro-Beyioku, W. A. Oyibo, and B. C. Anuforom, "Disinfectant/antiparasitic activities of Jatropha curcas," East African Medical Journal, vol. 75, no. 9, pp. 508-511, 1998.

[5] I. T. Matsuse, Y. A. Lim, M. Hattori, M. Correa, and M. P. Gupta, "A search for anti-viral properties in Panamanian medicinal plants. The effects on HIV and its essential enzymes," Journal of Ethnopharmacology, vol. 64, no. 1, pp. 15-22, 1998.

[6] A. M. Mujumdar, A. V. Misar, M. V. Salaskar, and A. S. Upadhye, "Antidiarrhoeal effect of an isolated fraction (JC) of Jatropha curcas roots in mice," Journal of Natural Remedies, vol. 1, pp. 8993, 2001.

[7] O. O. Igbinosa, E. O. Igbinosa, and O. A. Aiyegoro, "Antimicrobial activity and phytochemical screening of stem bark extracts from Jatropha curcas (Linn)," African Journal of Pharmacy and Pharmacology, vol. 3, no. 2, pp. 058-062, 2009.

[8] O. O. Igbinosa, I. H. Igbinosa, V. N. Chigor et al., "Polyphenolic contents and antioxidant potential of stem bark extracts from Jatropha curcas (Linn)," International Journal of Molecular Sciences, vol. 12, no. 5, pp. 2958-2971, 2011.

[9] R. Balaji, V. Suba, N. Rekha, and M. Deecaraman, "Hepatoprotective activity of methanolic fraction of Jatropha curcas on aflatoxin b1 induced hepatic carcinoma," International Journal of Physical Sciences, vol. 2, pp. 287-296, 2009.

[10] M. M. Goonasekera, V. K. Gunawardana, K. Jayasena, S. G. Mohammed, and S. Balasubramaniam, "Pregnancy terminating effect of Jatropha curcas in rats," Journal of Ethnopharmacology, vol. 47, no. 3, pp. 117-123, 1995.

[11] H. P. S. Makkar, K. Becker, F. Sporer, and M. Wink, "Studies on nutritive potential and toxic constituents of different provenances of Jatropha curcas," Journal of Agricultural and Food Chemistry, vol. 45, no. 8, pp. 3152-3157, 1997.

[12] M. Hirota, M. Suttajit, H. Suguri et al., "A new tumor promoter from the seed oil of Jatropha curcas L., an intramolecular diester of 12-deoxy-16-hydroxyphorbol," Cancer Research, vol. 48, no. 20, pp. 5800-5804, 1988.

[13] E. Chivandi, S. M. Makuza, K. H. Erlanger, J. P. Mtimuni, J. S. Read, and M. Tivapasi, "Effects of dietary Jatropha curcas on the haematology of weaned pigs," Zimbabwe Veterinary Journal, vol. 31, no. 4, pp. 83-91, 2000.

[14] W. S. Abdel Gadir, T. O. Onsa, W. E. M. Ali, S. M. A. El Badwi, and S. E. I. Adam, "Comparative toxicity of Croton macrostachys, Jatropha curcas and Piper abyssinica seeds in Nubian goats," Small Ruminant Research, vol. 48, no. 1, pp. 61-67, 2003.

[15] S. R. Mariz, W. C. Arauojo, G. S. Cerqueira et al., "Avaliacao histopatologica em ratros apos tratamento agudo com o extrato etanolico de partes aereas de Jatropha gossypifolia L.," Brazilian Journal of Pharmacognsosy, vol. 18, pp. 213-216, 2008.

[16] C. Chomchai, W. Kriengsunthornkij, T. Sirisamut, T. Nimsomboon, W. Rungrueng, and U. Silpasupagornwong, "Toxicity from ingestion of Jatropha curcas ('saboo dum') seeds in thai children," Southeast Asian Journal of Tropical Medicine and Public Health, vol. 42, no. 4, pp. 946-950, 2011.

[17] C. G. Rousseaux and H. Schachter, "Regulatory issues concerning the safety, efficacy and quality of herbal remedies," Birth Defects Research B, vol. 68, no. 6, pp. 505-510, 2003.
[18] F. Firenzuoli and L. Gori, "Herbal medicine today: clinical and research issues," Evidence-based Complementary and Alternative Medicine, vol. 4, no. 1, pp. 37-40, 2007.

[19] L. B. Seeff, "Herbal hepatotoxicity," Clinics in Liver Disease, vol. 11, no. 3, pp. 577-596, 2007.

[20] J. L. Tang, B. Y. Liu, and K. W. Ma, “Traditional Chinese medicine," The Lancet, vol. 372, no. 9654, pp. 1938-1940, 2008.

[21] H. Azaizeh, S. Fulder, K. Khalil, and O. Said, "Ethnobotanical knowledge of local Arab practitioners in the Middle Eastern region," Fitoterapia, vol. 74, no. 1-2, pp. 98-108, 2003.

[22] A. Gurib-Fakim, "Medicinal plants: traditions of yesterday and drugs of tomorrow," Molecular Aspects of Medicine, vol. 27, no. 1, pp. 1-93, 2006.

[23] C. I. Bliss, “The method of probits," Science, vol. 79, no. 2037, pp. 38-39, 1934.

[24] D. Finney, Probit Analysis: A Statistical Treatment of the Sigmoid Response Curve, Cambridge University Press, Cambridge, UK, 2nd edition, 1952.

[25] Q. X. Li, H. Wang, Q. Q. Xiao, and R. Kong, "The evaluation and calculation of Median Lethal Dose $\left(\mathrm{LD}_{50}\right)$ using Bliss method," Journal of Mathematical Medicine, vol. 4, pp. 318-320, 1995.

[26] M. Wink, M. Koschmieder, and S. Sauerwein, "Phorbol esters of Jatropha curcas Biological activities and potential applications," in Biofuel and Industrial Products From Jatropha curcas, G. M. Gubitz, M. Mittelbach, and M. Trabi, Eds., pp. 160-166, 1997.

[27] K. D. Rakshit, J. Darukeshwara, K. Rathina Raj, K. Narasimhamurthy, P. Saibaba, and S. Bhagya, "Toxicity studies of detoxified Jatropha meal (Jatropha curcas) in rats," Food and Chemical Toxicology, vol. 46, no. 12, pp. 3621-3625, 2008.

[28] D. R. Finco, "Kidney function," in Clinical Biochemistry of Domestic Animals, J. J. Kaneko, J. W. Harvey, and M. L. Bruss, Eds., pp. 441-484, Harcourt Brace and Company Asia PTE. Limited, Singapore, 5th edition, 1997.

[29] V. Awasthy, V. P. Vadlamudi, K. M. Koley, B. K. Awasthy, and P. K. Singh, "Biochemical changes after short-term oral exposure of Jatropha curcas seeds in wistar rats," Toxicology International, vol. 17, no. 2, pp. 67-70, 2010.

[30] B. C. Tennant, "Hepatic function," in Clinical Biochemistry of Domestic Animals, J. J. Kaneko, J. W. Harvey, and M. L. Bruss, Eds., pp. 327-352, Harcourt Brace and Company Asia PTE. Limited, Singapore, 5th edition, 1997.

[31] O. M. Ahmed and S. E. Adam, "Toxicity of Jatropha curcas in sheep and goats," Research in Veterinary Science, vol. 27, no. 1, pp. 89-96, 1979.

[32] S. E. I. Adam and M. Magzoub, "Toxicity of Jatropha curcas for goats," Toxicology, vol. 4, no. 3, pp. 388-389, 1975.

[33] H. J. Zhou, Statistical Methods for Biological Test, People's Medical Publishing House, Beijing, China, 1988.

[34] R. Y. Sun, NDST (New Drug Statistic) Version 8. 0, Wan-Nan Medical College, Wuhu, China, 1998. 

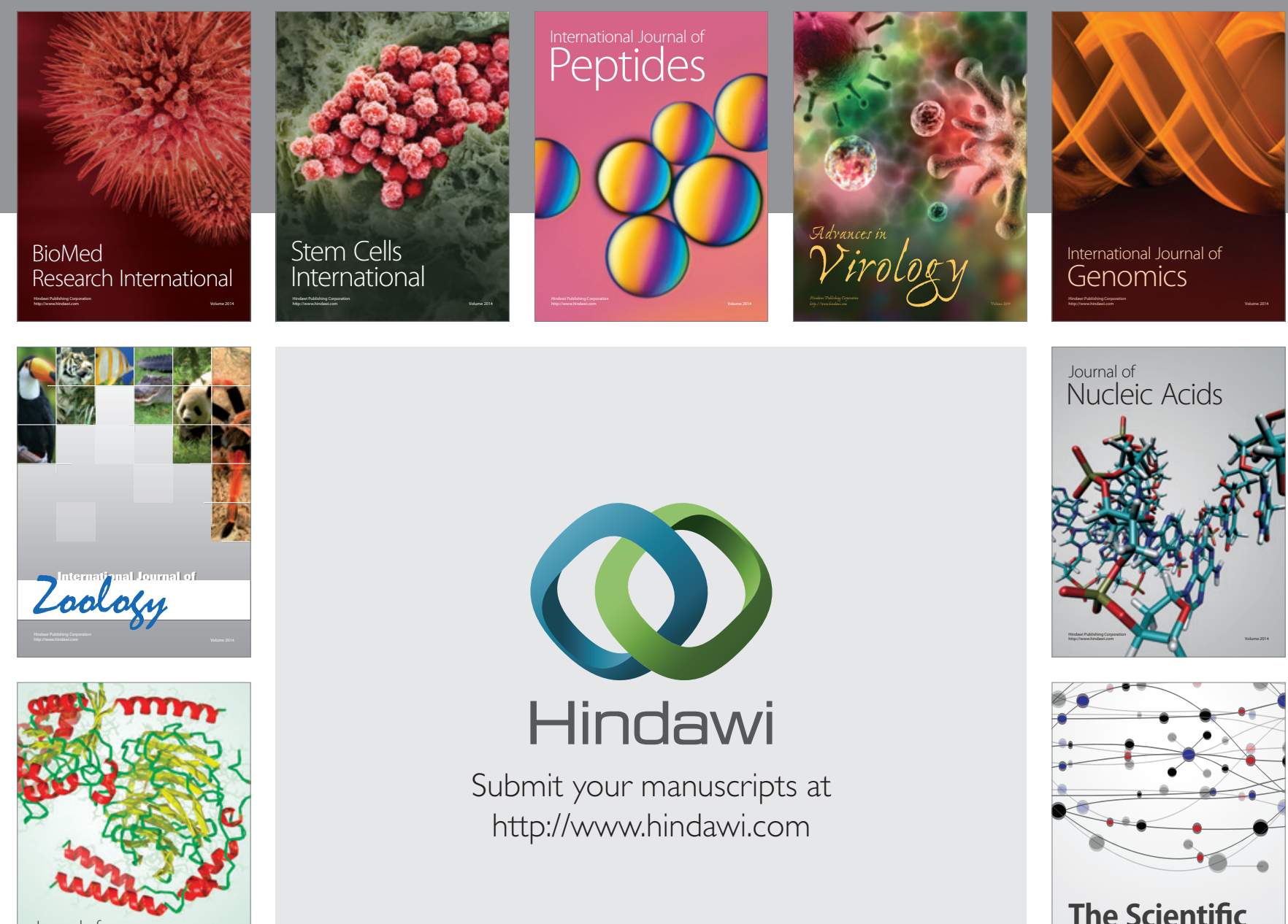

Submit your manuscripts at

http://www.hindawi.com

Journal of
Signal Transduction
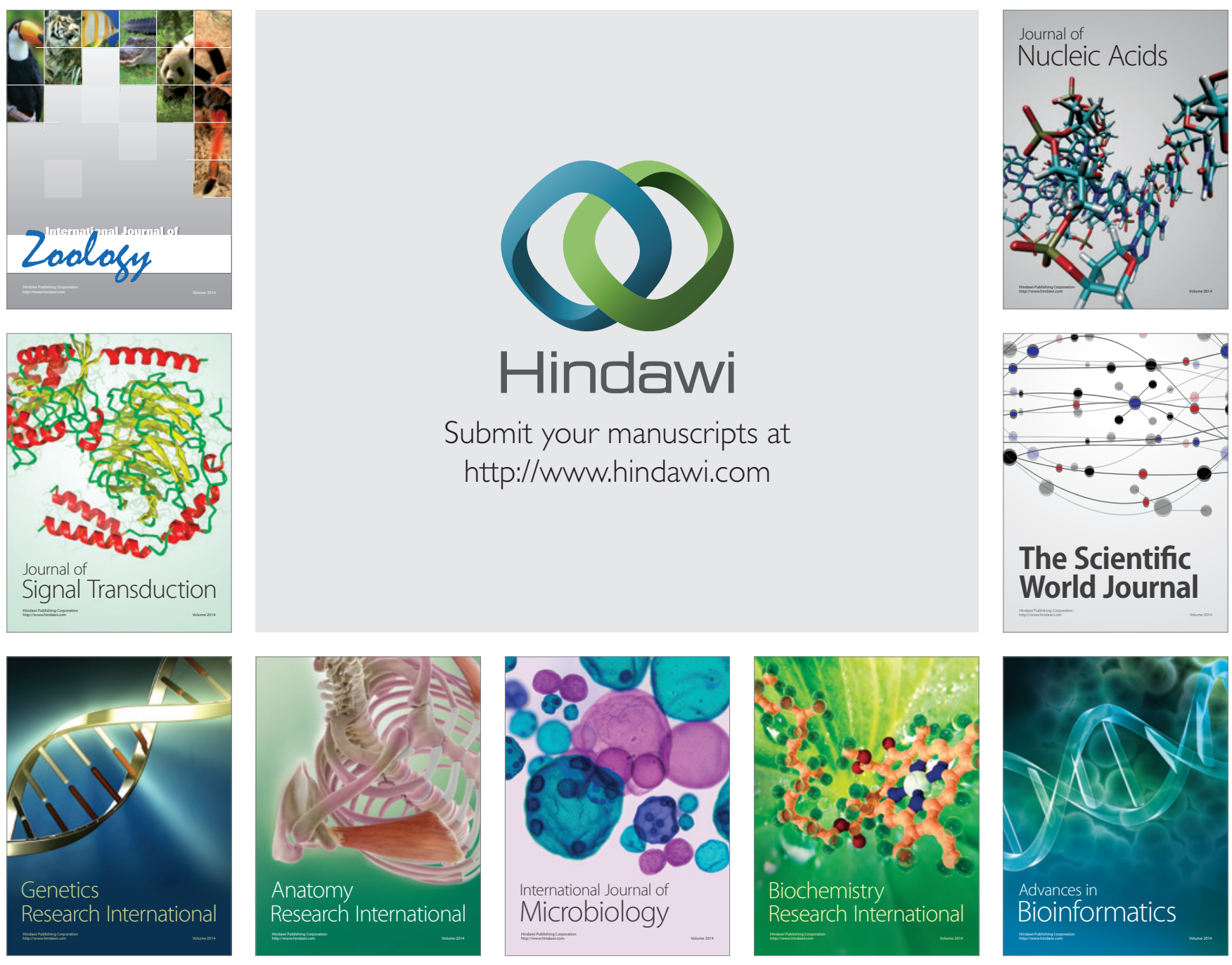

The Scientific World Journal
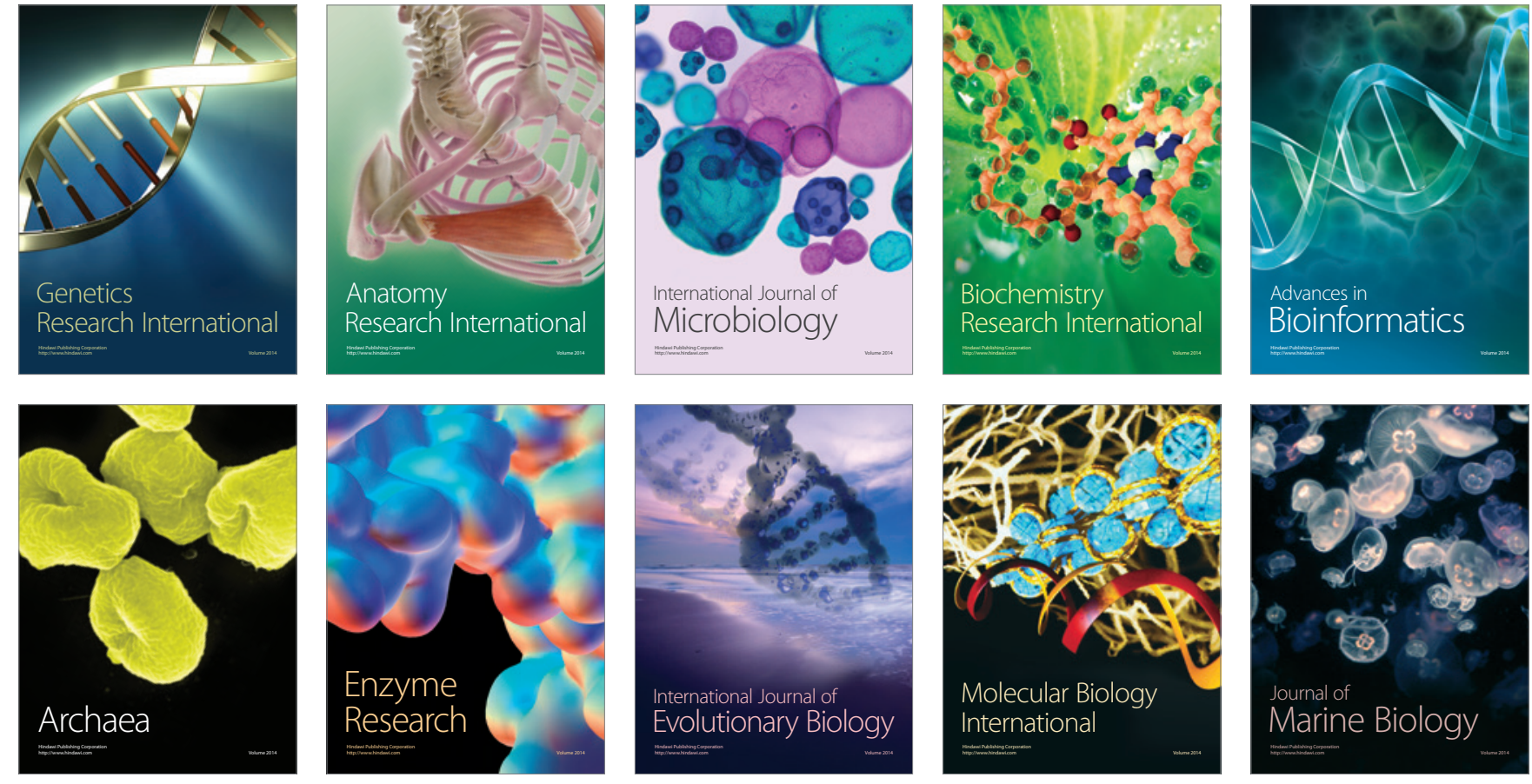